\title{
Attitude of Teachers towards Women Leadership of Secondary Schools in Ilorin, Kwara State
}

\author{
Alexander O. Iyekolo \\ Ph.D., Department of Social Sciences Education, Faculty of Education, University of Ilorin, Nigeria, \\ iyekolo.ao@gmail.com \\ Ifeoma P. Okafor \\ Ph.D., Department of Social Sciences Education, Faculty of Education, University of Ilorin, Nigeria, \\ ifeomapokafor@gmail.com
}

Isiaka Abdulaziz

Ph.D., Department of Social Sciences Education, Faculty of Education, University of Ilorin, Nigeria, isiakaabdulaziz@gmail.com

\footnotetext{
The study was a survey of secondary school teachers' attitude towards women leadership of secondary schools in Ilorin Metropolis. The study population comprises all public secondary school teachers in Ilorin Metropolis. From the population, random sampling technique was used to sample a total of 500 secondary school teachers across 20 randomly selected public secondary schools in the metropolis. The samples were further stratified on the basis of gender and year of experience. Data were collected using a researcher-designed questionnaire entitled Women School Leadership Questionnaire (WSLQ) and collected data were analyzed using percentages and t-test statistics. Findings revealed that $35.4 \%(\mathrm{n}=177)$ secondary school teachers preferred women as principals. $37.4 \%(n=187)$ as Vice-Principals and just $9.8 \%(n=47)$ never wanted women as school leaders. On the other hand, $81 \%(\mathrm{n}=405)$ of respondents believed that women school leadership is characterized by financial prudence. $29.8 \%(\mathrm{n}=149)$ agreed women school leadership encouraged collaborative approach to school governance. 12\% $(n=60)$ believed it led to domination of school activities by the women and $40.2 \%(n=201)$ believed having women as principals made schools well organized. At the level of hypotheses testing, it was found that secondary school teacher's preference of women as principals did not differ on the basis of gender of the teachers but differed on the length of teachers' teaching experience. It was therefore, concluded that appointing women as school principals may not be rejected by male and female subordinates as such appointment may even bring about financial prudence and organized school environment at secondary school level. Thus. it was recommended that more women should be encouraged and appointed to become principals in Nigerian secondary schools.
}

Keywords: attitude, teachers, women, leadership, secondary school, women leadership

\section{INTRODUCTION}

School leadership is an integral part of school development. It is one of the factors that determine the progress of achieving educational goals. This is because, school leadership anchors policy formulation, implementation and assessment in educational institutions. In confirmation of the importance of school leadership in school achievement, a study revealed that many school staff

Citation: Iyekolo, A. O., Okafor, I. P., \& Abdulaziz, I. (2020). Attitude of Teachers towards Women Leadership of Secondary Schools in Ilorin, Kwara State. Anatolian Journal of Education, 5(1), 135-140. https://doi.org/10.29333/aje.2020.5113a 
believed that it is the leader of the school and not the subordinates that determine and guide the culture of school progress. Subordinates often believe that it is the responsibility of the school leaders to create the required kind of atmosphere where school staff and students can be happy and successful in the achievement of school goals (Luthan. 2005). No doubt, school leaders form the pedestal on which the school effectiveness is laid. Without good school leadership, the available school resources may not be adequately utilized for school development.

Scholars have defined leadership in terms of group processes, personality, compliance, particular behaviours, persuasions, power, goal achievement, interaction, and role differentiation, initiation of structure, and combination of two or more of these (Edward, 2000; Deross, 2009). In their series of definitions, leadership and leadership effectiveness are not tied to gender quality or attributes nor are they seen as what is solely in the terrain of the male. School leadership, in particular, is said to be attainable on the basis of structured organizational job promotion, years of service and qualification. The process of becoming a school leader, mostly in public schools, is open to all teachers. Thus, as teachers grow in years of experience and qualification in line with the stipulation of the nation's Civil Service Law, so they move close to becoming school heads. However, in private secondary schools, school leadership often depends on ownership. Owners of private secondary schools, in most cases, transform to become the principals or in most cases exercise veto power to determine who becomes the school head.

Many have asked whether women get a chance of becoming school heads in Nigerian primary and secondary schools. In a study conducted by Rayo (2010) in Nigeria, it was discovered that many primary and secondary schools in Nigeria are under the leadership of women. Rayo emphatically gave the percentage of primary schools where women are the Headmistress as 53\%. This implies that women out numbered men in the leadership of Nigerian primary schools. A close observation, however, reveals that it is in the lower level of education that women are adequately represented as staff and leaders of educational institutions in Nigeria. For example, as indicated by Ayinla, Muhammed and Adeoye (2006), employment into and leadership of tertiary education in Nigerian universities is dominated by masculine folks. They indicated that only $13 \%$ of academic staff in Nigerian universities are women as compared to $33 \%$ in the United Kingdom. In addition to this, only $5 \%$ of all academic staff that occupy professorial posts are women in contrast to $7 \%$ in the United Kingdom.

Societal view of women leadership may be influenced by people's perception of women in the cultural society. In most cases, women are not as favoured as men in social activities. The world itself is dominated by men and so many often see women as second fiddle irrespective-of experience and qualification. Dauda (2000) pointed out that women are often expected to be mere assistants to men and are not expected to take leadership roles. But in situations where women become leaders by virtue of official placement, what is likely to be the attitude of men and women subordinates towards them?

Women leadership of educational institutions can be viewed in three ways. One way is to consider the numerical representation of women in leadership cadre, another is to consider their effectiveness, and yet another is to consider the attitude of staff under them (women school leaders) to their leadership principles and styles. In this study, the researcher finds out secondary school teachers' attitude towards women leadership of their schools. Specifically, the study was structured to identify preference of secondary school teachers for women school heads among male and female subordinates. The study also finds out teachers' perceived effectiveness and features of women leaders of secondary schools in Ilorin metropolis.

\section{Research Questions}

The following research questions guided the conduct of this study: 
1. Do secondary school teachers in Ilorin metropolis prefer women as school leaders'?

2. What are the perceived attributes of women leadership among secondary school teachers in Ilorin metropolis?

\section{Research Hypotheses}

The following null hypotheses were raised and tested in the process of conducting the study:

Ho1: There is no significant difference in male and female teachers' preference of leadership of women school heads in Ilorin metropolis.

Ho2: There is no significant difference in experience and less experience teacher's preference of leadership of women school heads in Ilorin metropolis.

\section{METHOD}

The study was a survey of secondary school teachers' attitude towards women leadership of educational institutions in Nigeria. The population for the study comprises: every public secondary school teacher in Ilorin Metropolis. From the population, random sampling technique was used to sample a total of 500 secondary school teachers (250 male teachers and 250 female teachers) across 20 randomly selected public secondary school; from the 56 located in the metropolis. The 500 sampled were further stratified on the basis of gender and length of experience. Data were collected using a researcher-designed questionnaire titled Women School Leadership Questionnaire (WSLQ). The questionnaire had two sections. Section 'A' elicited respondents" biographical data while Section 'B had two parts. Part I contained items testing teachers' preference and perceived attributes of women school heads. The Part II of the Section "B" contained items testing teachers' general attitude towards women leadership of a school where they work. This part tested respondents' readiness to obey, collaborate and reference women school leaders if they find themselves serving under such women.

The validity of the instrument was determined using content and face validity approaches. The validation was done by five experts in Measurement and Evaluation and their opinion were incorporated to the final draft of the instrument. On the other hand, test re-test technique was used to determine the reliability of the instrument and a coefficient of 0.76 was obtained. Collected data were analyzed using percentages and t-test statistics.

\section{FINDINGS}

Research Question 1: Do secondary school teachers in Ilorin Metropolis prefer women as school leaders?

Table 1

Preference of Women School Leaders in Secondary School

\begin{tabular}{llllllll}
\hline & & Male & Teachers & \multicolumn{2}{c}{ Female Teachers } & \multicolumn{2}{c}{ Total } \\
& & $\mathrm{n}$ & $\%$ & $\mathrm{n}$ & $\%$ & $\mathrm{n}$ & $\%$ \\
\hline 1 & Prefer women as Principals & 98 & 39.2 & 79 & 31.6 & 177 & 35.4 \\
2 & Prefer women only as Vice-Principals & 103 & 41.2 & 84 & 33.6 & 187 & 37.4 \\
3 & Prefer women only as Head of Department & 33 & 13.2 & 56 & 22.4 & 89 & 17.8 \\
4 & Never want a woman as School Heads & 16 & 6.4 & 31 & 12.4 & 47 & 9.8 \\
\hline
\end{tabular}

Data on Table 1 indicate that out of the sampled 250 male teachers, $39.2 \%$ of them preferred women as principals, while out of the 250 sampled female teachers, $31.6 \%$ preferred women principals. Also, $41.2 \%$ of male teachers sample preferred women as only Vice-Principals and not as principals, while $33.6 \%$ of sampled female teachers would want women only as Vice Principals. Also, while $13.2 \%$ male respondents wanted women only as Heads of Department, $6.4 \%$ of them never even wanted 
women as school heads. However, $22.4 \%$ of sampled female respondents wanted women only as Heads of Department in schools and $12.4 \%$ never wanted women to head any aspect of school.

Research Question 2: What are the perceived attributes of women leadership among secondary school teachers in llorin metropolis?

Table 2

Perceived Attribute of Women School Leadership

\begin{tabular}{|c|c|c|c|c|c|c|c|}
\hline & & \multicolumn{2}{|c|}{ Male Teachers } & \multirow{2}{*}{$\begin{array}{l}\text { Female } \\
\mathrm{N}\end{array}$} & \multirow{2}{*}{$\begin{array}{l}\text { Teachers } \\
\%\end{array}$} & \multicolumn{2}{|l|}{ Total } \\
\hline & & $\mathrm{n}$ & $\%$ & & & $\mathrm{n}$ & $\%$ \\
\hline 1 & Financial Prudence & 199 & 79.6 & 206 & 82.4 & 405 & 81 \\
\hline 2 & $\begin{array}{l}\text { Collaborative approach to school } \\
\text { governance Domination of school activities }\end{array}$ & $\begin{array}{l}87 \\
26\end{array}$ & $\begin{array}{l}34.8 \\
10.4\end{array}$ & $\begin{array}{l}62 \\
34\end{array}$ & $\begin{array}{l}24.8 \\
13.6\end{array}$ & 14960 & 29.812 \\
\hline 3 & Organized school (physical \& policy)*. & 103 & 41.2 & 98 & 39.2 & 201 & 40.2 \\
\hline 4 & School indiscipline & 17 & 6.8 & 23 & 40 & 57 & 11.4 \\
\hline
\end{tabular}

As shown on Table 2 above, $81 \%$ of sampled male and female secondary school teachers agreed that whenever women are principals, there is always financial prudence in handling of school fund, $29.8 \%$ believed such women school leaders always adopt collaborative approach to school governance, $12 \%$ agreed that women school leaders dominate school activities, 40.2\% agreed that when women lead school, the school is well organized physically and in term of school policy, and $11.4 \%$ agreed that women leadership of school is often characterized by school indiscipline.

\section{Research Testing}

Ho1: There is no significant difference in male and female teachers' preference of leadership of women school heads

Table 3

t-test Analysis of Preference of Women Leadership of Secondary Schools on the Basis of Gender

\begin{tabular}{llllllll}
\hline Teacher & $\mathrm{N}$ & $\mathrm{X}$ & $\mathrm{Sd}$ & $\mathrm{df}$ & $\mathrm{t}$-cal & t-crit & $\mathrm{p}$-value \\
\hline Male & 250 & 43.7 & 12.31 & 498 & \multirow{2}{*}{1.58} & \multirow{2}{*}{1.96} & .367 \\
Female & 250 & 44.2 & 13.11 & & & \\
\hline
\end{tabular}

Data on Table 3 shows that the calculated t-test value, 1.58 is less than the t-critical value, 1.96. Therefore, it was concluded that there was no significant difference in in male and female teachers' preference of leadership of women school heads.

Ho2: There is no significant difference in experience and less experience teachers' preference of leadership of women school heads in Ilorin metropolis.

Table 4

$\mathrm{t}$-test Analysis of Preference of Women Leadership of Secondary Schools on the Basis of Experience

\begin{tabular}{llllllll}
\hline Experience & $\mathrm{N}$ & $\mathrm{X}$ & $\mathrm{SD}$ & $\mathrm{df}$ & $\mathrm{t}$-cal & t-crit & $\mathrm{p}$-value \\
\hline Long Term & 259 & 53.6 & 11.4212 .51 & 498 & 2.11 & 1.96 & .001 \\
Short Term & 241 & 51.4 & & & \\
\hline
\end{tabular}

Data on Table 4 shows that the calculated t-test value, 2.11 is higher than the critical value. 1.96. Therefore, hypothesis 2 was rejected and it was concluded that there was a significant difference in experienced and less experienced secondary school teachers' preference of women school principals.

\section{DISCUSSION}

Secondary school education is an important level of education in Nigeria. It is a level of education that requires adequate and effective administrative efforts form Ministry of Education and stationed school 
leaders. Being a level of education that bridges students' educational endeavour from elementary to tertiary stages of schooling, secondary schools remain the most vital aspect of Nigerian system of education, where school personnel are expected to display administrative principles and practices that can ensure productive utilization of human and non-human resources. Series of researches already revealed that this level of education is under the control of male and female school heads. It was however, revealed in Rayos (2000) that substantial percentage $(48.4 \%)$ of secondary schools in Nigeria is under the headship of women in Nigeria. Also, Rayo (2010) discovered that many primary and secondary schools in Nigeria are under the leadership of women. This implies that women are not segregated in terms of appointment as principals in Nigeria.

Unfortunately, in Nigerian traditional societies, there are socio-cultural practices that oftenpredetermined what people expect from women. who are appointed as leaders, even outside the educational sector? As explained by Ageola (2003), Nigerians often believe that women are inferior to men and are incapable of making sound decisions or present a logical leadership attributes and strategies. Thus, there may be negative or unsupportive disposition towards women leadership. On this premise, it may be presumed that secondary school teachers may prefer men as principals to women.

However, as shown in the findings of this study, many secondary school teachers preferred women to men as principals. Specifically. 39.2\% of sampled male teachers within Ilorin metropolis preferred women as principals, while $31.6 \%$ of the sampled female teachers also preferred women as their principals. The findings also indicated that $41.2 \%$ of male sampled preferred male and $33.6 \%$ of male teachers wanted women only as Vice-Principals. In fact, only $9.8 \%$ of the total sampled 500 male and female teachers never wanted women as secondary school principals in the metropolis. These findings are significant as they point to the fact that male teachers, even prefer women principals more than the way female teachers wanted women principals.

Many reasons for preference of women as principals may be deduced from the second stage of the analysis of the findings of this study. At this stage, respondents were asked to indicate attributes of women school headship. Fortunately. $81 \%$ of male and female sampled teachers were of the opinion that where women serve as principals, there was always financial prudence. This implies that women leadership of secondary schools lead to careful decision making in the management of school fund. This is important as it will ensure adequate utilization of school funds for school growth than for personal aggrandizement. These findings may even point to the possibility of appointing women to correct financial anomalies in schools. In addition to this finding, $40.2 \%$ of sampled teachers agreed that secondary schools' women govern are always well organized in term of physical and policy structuring.

However. $11.4 \%$ of sampled respondents were of the opinion that women governance of secondary schools may lead to increase in school indiscipline. This is negative. The perception of the sampled teachers may be based on the cultural belief that women are soft in implementing and or sanctioning misapplication of rules and regulations (Faderera, 2002). Faderera asserts that in traditional society, people already assume women cannot take firm decision that can prevent illogicalities and administrative errors. This may be what informed the sampled teachers to assume having women as school heads will lead to school indiscipline. In whatever form, the findings extol women as possible better leaders for Nigerian secondary schools. This fact is more pronounced with the fact that even sampled men were in support of the effective capacity of women as school leaders.

\section{CONCLUSION}

The study investigated attitude of teachers towards women leadership of Secondary Schools in Ilorin, Kwara State. The findings revealed that $35.4 \%$ secondary school teachers preferred women as principals. $37.4 \%$ as Vice-Principals and just $9.8 \%$ never wanted women as school leaders. On the 
other hand, $81 \%$ of sampled respondents believed that women school leadership is characterized by financial prudence. $29.8 \%$ agreed women school leadership encouraged collaborative approach to school governance. $12 \%$ believed it led to domination of school activities by the women and $40.2 \%$ believed having women as principals made schools well organized. At the level of hypotheses testing, it was found that secondary school teacher's preference of women as principals did not differ on the basis of gender of the teachers but differed on the length of teachers' teaching experience.

\section{RECOMMENDATIONS}

Based on the findings of this study, the following are recommended for the Nigerian system of education.

1. Government and other stakeholders in education industry should be encouraged to promote policies and practices that will lead to the appointment of women as school principals in Nigerian secondary schools.

2. Women appointed as school heads should be conscious of indiscipline among staff and students. They are to come up with clear rules, regulations and school management strategies that will help them step down cases of indiscipline that can undermine their authorities in school.

\section{REFERENCES}

Ageola, W. I. (2003). Cultural beliefs and gender authorities in Nigerian traditional societies: Journal of Cultural Studies in Africa, 3(4), 34-51

Ayinla, S. A., Muhammed, A. Y., \& Adeoye, M. N. (2006). Education and regeneration of traditional values in Nigeria. Lagos: University of Lagos Press.

Dauda. B. G. (2000). Value, roles and gender orientation in Nigerian communities. Abeokuta: Franco Media.

Deross. L. M. (2009). Organizational behaviour. Philadelphia: Westminister.

Edward. K. P. (2000). Social diversities and globalization. New York: Stage Publication.

Faderera, S. S. (2002). Women and leadership. Lagos: Olorogun. Publication and Art Impressions.

Luthan, F. (2005). Organizational behaviour. New York: McGraw Hill.

Rayo, D. E. (2010). Assessment of gender representation in Nigerian secondary and primary school leadership. Journal of National Association of Educational Administrators in Nigeria, 2(3).

Tajfel, H. (1982). Social identity <md group relations. Cambridge: Cambridge University Press

Horowitz, L. A., \& Bordens, K. S. (1995). Social psychology. Tokyo. 